\title{
Heavy-mineral and garnet compositions of stream sediments and HP-UHP basement rocks from the Western Gneiss Region, SW Norway
}

\author{
Anne Krippner', Guido Meinhold', Andrew C. Morton² \& Hilmar von Eynatten' \\ ${ }^{1}$ Department of Sedimentology and Environmental Geology, University of Göttingen, Goldschmidtstraße 3, 37077 Göttingen, Germany. \\ ${ }^{2}$ CASP, West Building, 181A Huntingdon Road, Cambridge CB3 ODH, United Kingdom and HM Research Associates, Orbayu, Grove Road, \\ St Ishmaels, Haverfordwest, SA62 3TG, United Kingdom.
}

E-mail corresponding author (Anne Krippner): anne.krippner@geo.uni-goettingen.de

We present heavy-mineral and garnet geochemical data of recent stream sediments and HP-UHP bedrock from the Flatraket and Ulvesund plutonic bodies and from the island of Runde, Western Gneiss Region, SW Norway, to test to what extent the heavy minerals and the garnet geochemistry in stream sediments reflect the geological situation in the source area. The heavy-mineral assemblages of the stream sediments contain garnet, green calcic amphibole and epidote-group minerals, which reflect greenschist-facies and higher grade metamorphism in the source area. The geochemical data of garnets point to high-grade metamorphic conditions. Overall, the heavy-mineral and garnet geochemical data reflect the geological situation in the source area, which confirms the application and the importance of heavy minerals in sedimentary provenance analysis. Geochemical data of heavy minerals usually show a wider distribution in the sediments than the data of heavy minerals measured in the bedrock. However, our results demonstrate that this is not always the case. Some garnets measured in the bedrock, especially lower grade and ultrahighgrade metamorphic garnets, are only of secondary importance or they are lacking in the sediments. This probably results either from larger grain sizes of garnets in some source rocks than in the studied grain-size window of the sediments, or because those garnets are diluted by a high input of garnets from source rocks containing higher amounts of garnets.

Keywords: Provenance, Heavy minerals, Garnet geochemistry, Western Gneiss Region, Norway

Electronic Supplements:

Table S1: Heavy-mineral assemblages with and without opaque minerals.

Table S2: Groups of heavy-mineral assemblages.

Table S3: Garnet geochemical data of basement rocks and river sediments.

Table S4: Content of heavy minerals from the rock formations of Flakraket, Ulvesund and Runde.

Table S5: Thin-sections of some basement rocks showing grain sizes of garnets.

Received 4. September 2015 / Accepted 30. November 2015 / Published online 27. January 2016

\section{Introduction}

Detrital heavy minerals from sediments provide insights into the geology of the entire catchment area. Several techniques exist to analyse different mineral grains and every single grain preserves information about the tectonic and erosional history of the source areas (e.g., Garzanti et al., 2009; von Eynatten et al., 2012). However, numerous processes during the sedimentary cycle can affect the detrital grain signature (e.g., Morton \& Hallsworth, 1999). Therefore, it is important to learn more about these processes and to find ways to minimise potential bias. In this study,

Krippner, A., Meinhold, G., Morton, A.C. \& von Eynatten, H. 2015: Heavy-mineral and garnet compositions of stream sediments and HP-UHP basement rocks from the Western Gneiss Region, SW Norway. Norwegian Journal of Geology 96, 7-17. http://dx.doi.org/10.17850/njg96-1-02. 
we sampled three different small catchment areas in the Western Gneiss Region in order to test if the heavy-mineral and garnet geochemistry of the stream samples for the commonly used grainsize fraction of 63-125 $\mu \mathrm{m}$ reflects the geological situation in the source area. Some studies have shown that the use of a narrow grain size can give misleading results, because through physical processes detrital minerals are segregated according to their size, density and shape (Morton \& Hallsworth, 1999; Garzanti et al., 2008, 2009, 2010), even within a single mineral group (Schuiling et al., 1985; Andò, 2007; Garzanti et al., 2008). However, because sampling and sample preparation can be very time consuming, we wanted to test whether we are able to make inferences about the geology of the source area when only one sample is available and if only one grain-size fraction of the sample is considered. Garnet is very useful in sedimentary provenance analysis, because it exists in many different types of rock and its chemical composition can be correlated with the conditions under which the source rocks were formed (e.g., Andó et al., 2014; Krippner et al., 2014). With increasing pressure and temperature conditions in the source area, garnet shows progressive substitution from $\mathrm{Mn}^{2+}$ to $\mathrm{Fe}^{2+}$ and $\mathrm{Mg}^{2+}$ (Miyashiro, 1953; Nandi, 1967; Deer et al., 1992; Andó et al., 2014). Therefore, garnet has important provenance applications. However, there exist some overlaps between different garnet assemblages, which need to be considered carefully (see Krippner et al., 2014)

\section{Geological setting}

The Scandinavian Caledonides were formed during the continental collision between Baltica and Laurentia under closure of the Iapetus Ocean during the Silurian. The Western Gneiss Region (WGR) is generally interpreted to represent the westward continuation of the Fennoscandian basement of Baltica (e.g., Roberts \& Gee, 1985; Brueckner \& van Roermund, 2004; Root et al., 2005, Spengler et al., 2009). During the Scandian phase (435-390 $\mathrm{Ma}$ ) of the Caledonian orogeny, the subduction of Baltica beneath Laurentia produced high-pressure (HP) and ultrahigh-pressure (UHP) rocks (Griffin \& Brueckner, 1980, 1985; Gebauer et al., 1985; Mørk \& Mearns, 1986; Andersen et al., 1991; Krabbendam et al., 2000; Terry \& Robinson, 2004). The depth of subduction increases towards the northwest (Fig. 1; Andersen et al., 1991; Brueckner, 1998; Brueckner \& van Roermund, 2004; Hacker et al., 2010; Beyer et al., 2012). The WGR consists mainly of granodioritic to granitic orthogneisses and is considered to represent Baltican basement (Tucker et al., 1990). The gneisses are predominantly of amphibolite-facies metamorphic grade (Bryhni \& Andréasson, 1985; Krabbendam \& Wain, 1997; Krabbendam et al., 2000), but in some parts granulite-facies assemblages occur (Griffin et al., 1985; Krabbendam et al., 2000). The orthogneisses are locally overlain by pelitic paragneisses, but they are very scarce (Carswell \& Cuthbert, 2003). Within the gneisses, eclogite lenses and pods occur but they make up only 1 vol.\% of the HP-UHP terrane (Root et al., 2005). Following the UHP event, rocks of the WGR underwent a strong amphibolite-facies recrystallisation. Some of the eclogites survived this overprint, but many of the UHP minerals were replaced by amphibolite-facies minerals.

\section{Sampling areas}

Samples were collected from two drainage systems in the Nordfjord-Stadlandet area and from the island of Runde off the coast southwest of Ålesund (Fig. 1). Sampling sites at or near the river mouths were chosen in such a way that the stream samples have not been affected by reworking and mixing with sediments from coastal currents. In a glaciated terrain, pebbles collected from streams can be exotic and need to be considered carefully. In western Norway, the till cover is only very thin and discontinuous (Thoresen, 1990). Moreover, the composition of the till reflects the local bedrock composition, because most of those deposits were only transported over short distances (Tiberg, 1998). In this case, an exotic input can be neglected.

\section{Flatraket}

The Flatraket body (Fig. 2) is located within the UHP domain (Root et al., 2005) and the mixed HP-UHP transition zone (Wain, 1997) and preserves pre-Caledonian igneous and granulite-facies assemblages, which underwent little or no Caledonian deformation (Krabbendam et al., 2000). The main rock type of Flatraket is a micaceous quartzo-feldspathic gneiss with megacrystic K-feldspar which, in its core, equilibrated under amphibolite-facies conditions (Krabbendam et al., 2000). This gneiss is surrounded by a transition zone composed of felsic granulite gneisses. Within these gneisses, layers and pods of dioritic, anorthositic and mafic composition are preserved. The eclogites make up c. 5\% of the Flatraket area and are partially retrogressed to amphibolite-facies assemblages. The granulite is also strongly affected by amphibolite-facies retrogression (Krabbendam \& Wain, 1997; Wain et al., 2001).

The stream sample (AK-N13-1) was taken where the main river enters the sea (Fig. 2). Additionally, some source rocks were taken for comparison. Sample AK-N11 is a granulite of felsic composition with only a minor garnet content, sample AK-N16 is a mafic eclogite with a high content of garnet and sample $\mathrm{AK}-\mathrm{N}-12$ is a UHP eclogite of mafic composition with very high garnet content taken in outcrop; samples AK-N13-2a, AK-N13-2b, AK-N13-2c and $\mathrm{AK}-\mathrm{N} 13-2 \mathrm{~d}$ are pebbles taken from the river bed. Pebbles AK-N13-2a and AK-N13-2b are of mafic eclogitic composition with a high garnet content, samples AK-N13-2c and AK-N13-2d are felsic gneisses. In sample AK-N13-2c, garnets occur only in traces and in sample AK-N13-2d even fewer garnet grains are present. The geographic coordinates, compositions and garnet contents of all samples are given in Table 1.

\section{Ulvesund}

The Ulvesund body is located in the HP-UHP transition zone (Wain, 1997) and is mainly composed of medium- and finegrained, garnetiferous felsic gneiss, which contains relics of metamorphic (granulite-, eclogite- and amphibolite-facies) assemblages. Ultramafic pods have only a minor distribution in comparison with the Flatraket body. Most mafic pods are small with well equilibrated eclogite-facies assemblages (Krabbendam et al., 2000). 


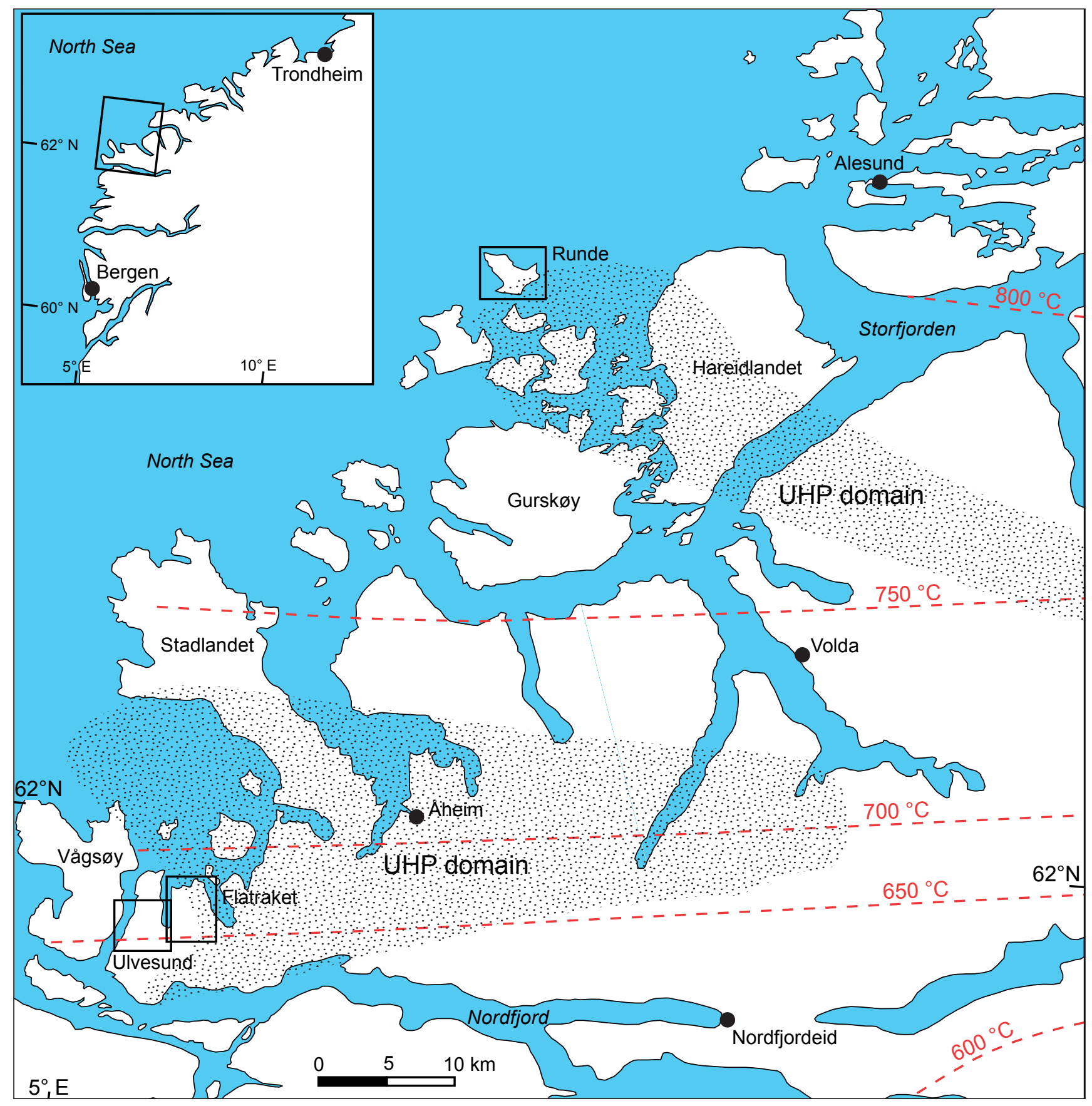

Figure 1. Map of the Western Gneiss Region showing ultrahigh-pressure (UHP) domains and peak metamorphic temperature isolines (after Root et al., 2005; Kylander-Clark et al., 2008; Wang et al., 2013). Boxes indicate locations of the study areas.

The Trollebøelva stream sample (AK-N8-1) was taken near the river mouth (Fig. 3). Additionally, some country rocks were collected from this area for comparison. Sample AK-N9-1 is a garnet-rich felsic granulite taken in outcrop; sample AK-N8-2 is a pebble of mafic eclogitic composition, also rich in garnets, collected from the river bed. The geographic coordinates, compositions and garnet contents of all samples are given in Table 1.

\section{Runde}

The island of Runde is located within a UHP domain, which is interpreted to be allochthonous relative to the WGR basement (Root et al., 2005; Beyer et al., 2012). The main rock type of the island of Runde is quartzo-feldspathic gneiss. The allochthonous cover units include different types of rock such as quartzites, mar- 


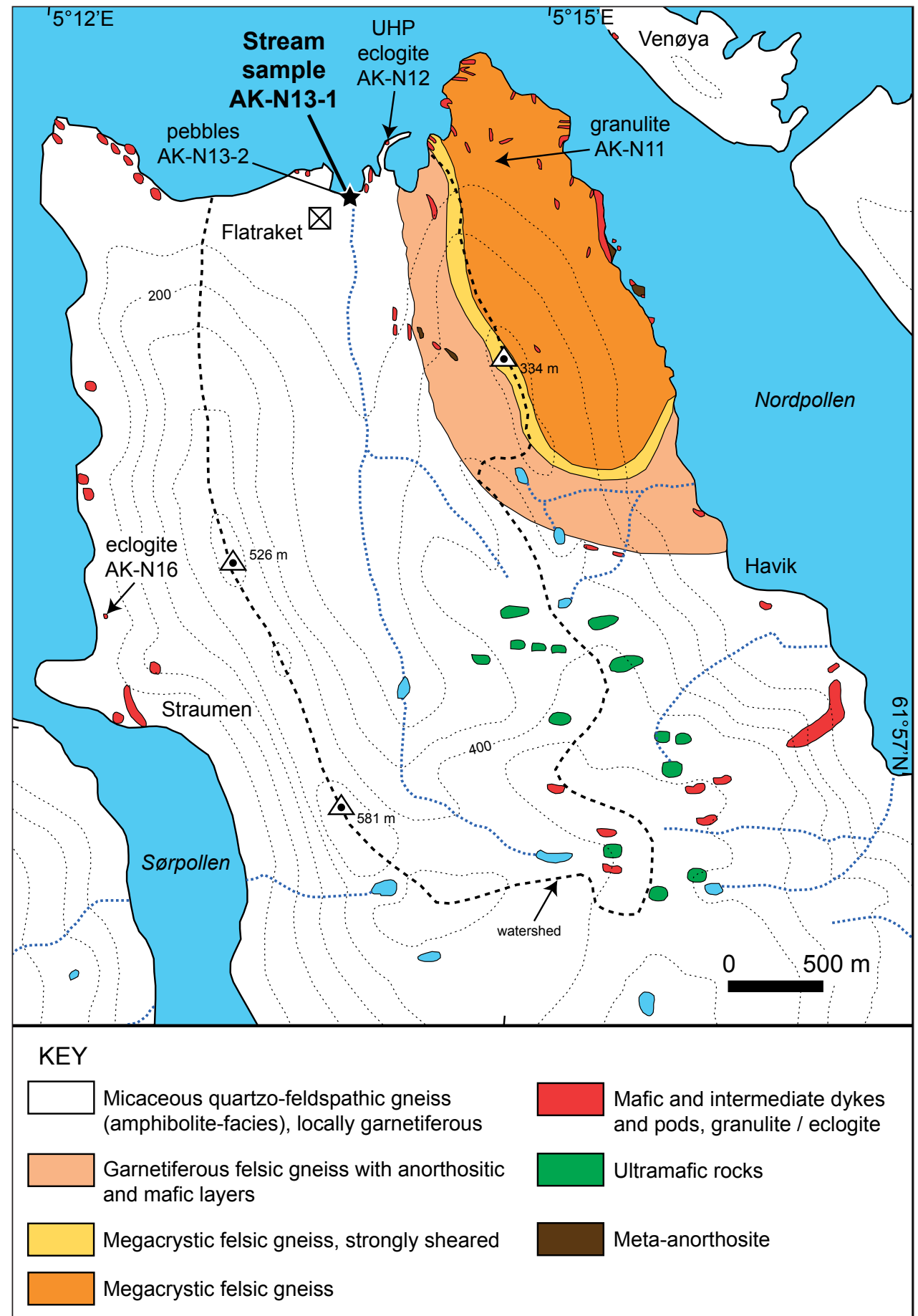

Figure 2. Map showing sample localities and the surrounding geology of the Flatraket area (compiled from Krabbendam et al., 2000; Carswell et al., 2003). Abbreviation: UHP - ultrahigh-pressure.

bles, calc-silicate gneisses, kyanite schists, augen gneisses, amphibolite and garnet-free peridotite, as well as eclogites, which makes this area more heterogeneous than the other two catchment areas (Root et al., 2005; Beyer et al., 2012).

The sample AK-N37 was taken from the beach on the southern side of the island (Fig. 4). Also, two bedrock samples were collected for comparison with the beach sample. Sample AK-N38 is a garnet-rich mafic eclogite and sample AK-N39-1 is a relatively garnet-rich, intermediate garnetiferous gneiss taken in outcrop. The geographic coordinates, compositions and garnet contents of all samples are given in Table 1. 
Table 1. Sample location data (WGS 84) of all samples (stream sediments and hardrocks), composition of hardrocks and garnet content.

\begin{tabular}{|c|c|c|c|c|c|c|}
\hline Sample & Type & Locality & Northing & Easting & Composition & Garnet content \\
\hline AK-N8-1 & stream & Ulvesund body & $61^{\circ} 56.565^{\prime}$ & $5^{\circ} 08.809^{\prime}$ & mafic & \\
\hline AK-N8-2 & pebble (eclogite) & Ulvesund body & $61^{\circ} 56.565^{\prime}$ & $5^{\circ} 08.809^{\prime}$ & mafic & + \\
\hline AK-N9-1 & granulite & Ulvesund body & $61^{\circ} 56.257^{\prime}$ & $5^{\circ} 08.565^{\prime}$ & felsic & + \\
\hline $\mathrm{AK}-\mathrm{N} 11$ & granulite & E of Flatraket & $61^{\circ} 58.703^{\prime}$ & $5^{\circ} 14.716^{\prime}$ & felsic & o \\
\hline AK-N12 & eclogite (UHP) & Flatraket harbour & $61^{\circ} 58.710^{\prime}$ & $5^{\circ} 14.063^{\prime}$ & mafic & ++ \\
\hline AK-N13-1 & stream & Flatraket & $61^{\circ} 58.554^{\prime}$ & $5^{\circ} 13.845^{\prime}$ & & \\
\hline AK-N13-2a & pebble (eclogite) & Flatraket & $61^{\circ} 58.554^{\prime}$ & $5^{\circ} 13.845^{\prime}$ & mafic & + \\
\hline AK-N13-2b & pebble (eclogite) & Flatraket & $61^{\circ} 58.554^{\prime}$ & $5^{\circ} 13.845^{\prime}$ & mafic & + \\
\hline $\mathrm{AK}-\mathrm{N} 13-2 \mathrm{c}$ & pebble (gneiss) & Flatraket & $61^{\circ} 58.554^{\prime}$ & $5^{\circ} 13.845^{\prime}$ & felsic & - \\
\hline $\mathrm{AK}-\mathrm{N} 13-2 \mathrm{~d}$ & pebble (gneiss) & Flatraket & $61^{\circ} 58.554^{\prime}$ & $5^{\circ} 13.845^{\prime}$ & felsic & o \\
\hline AK-N16 & eclogite & Flatraket & $61^{\circ} 57.281^{\prime}$ & $5^{\circ} 12.562^{\prime}$ & mafic & + \\
\hline AK-N37 & beach & Runde & $62^{\circ} 23.341^{\prime}$ & $5^{\circ} 38.252^{\prime}$ & & \\
\hline AK-N38 & eclogite & Runde & $62^{\circ} 24.212^{\prime}$ & $5^{\circ} 39.230^{\prime}$ & mafic & + \\
\hline AK-N39-1 & garnet gneiss & Runde & $62^{\circ} 24.012^{\prime}$ & $5^{\circ} 39.459^{\prime}$ & intermediate & o \\
\hline
\end{tabular}

++ - very high, + - high, o- medium, - - less.

Abbreviation: UHP - ultrahigh-pressure.

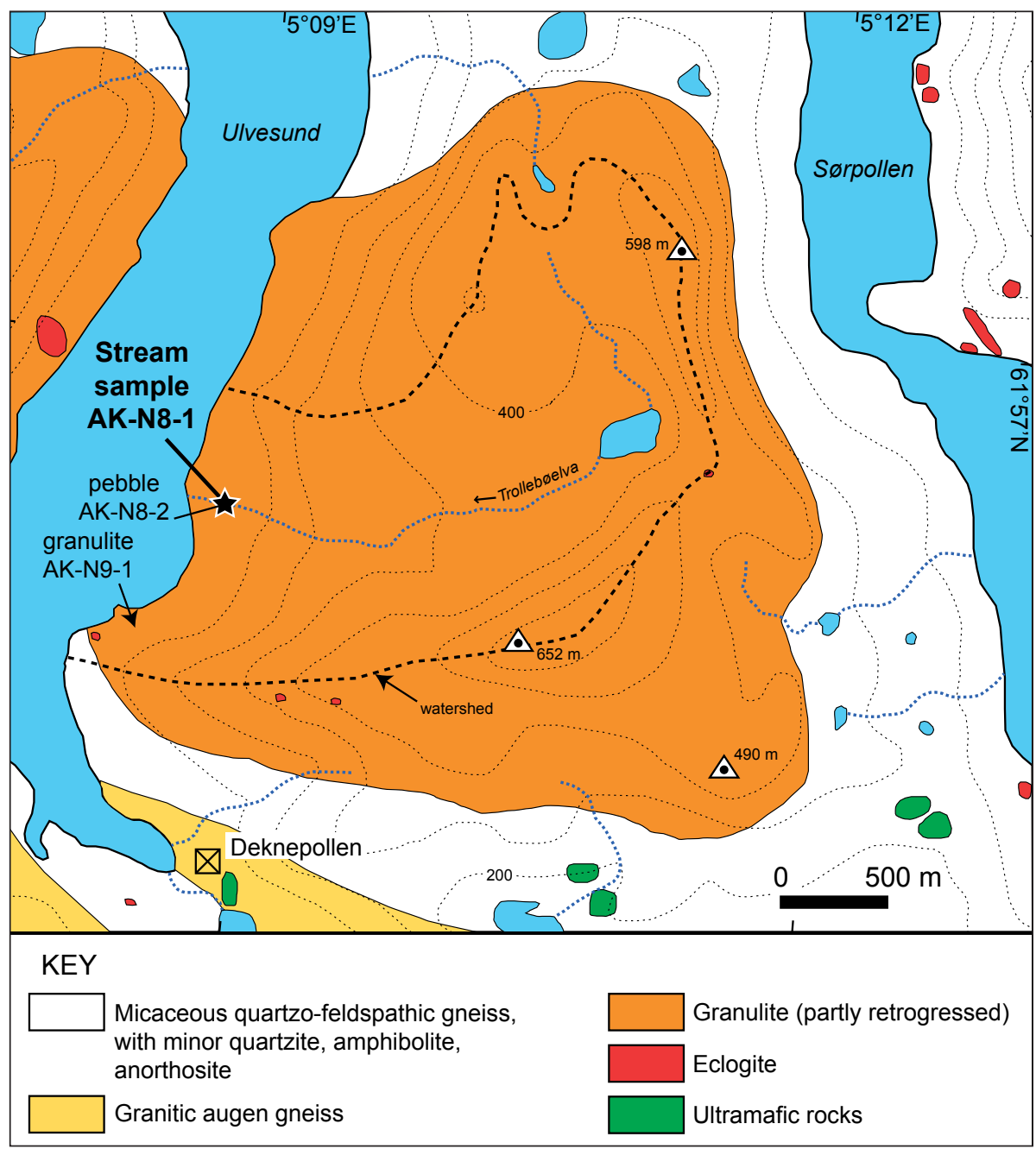

Figure 3. Map showing sample localities and the surrounding geology of the Ulvesund area (modified from Krabbendam et al., 2000). 


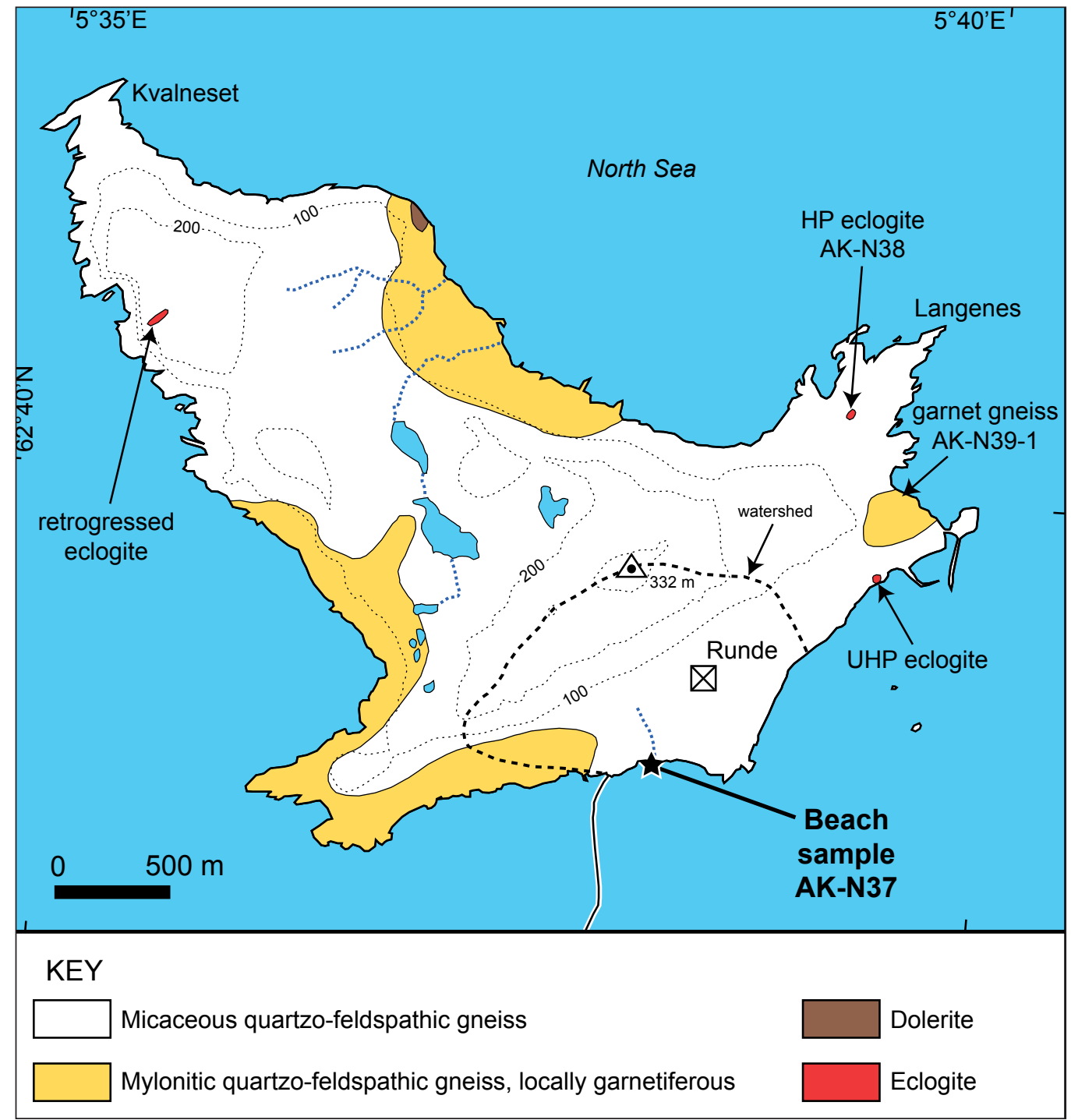

Figure 4. Map showing sample localities and the surrounding geology. Modified from a NGU map of Runde island (1:50,000) prepared by the NGU map generator (http://geo.ngu.no/kart/berggrunn/). The eclogite localities are also indicated (Root et al., 2005; Spencer et al., 2013; Bradley R. Hacker, pers. comm., 2014; own field observations). Abbreviations: HP - high-pressure, UHP - ultrahigh-pressure.

\section{Methods}

Recent fluviatile deposits near or directly at the river mouth were sampled. In addition, bedrock samples were collected since they represent the source for the detrital material. Bedrock samples were taken in outcrop and pebbles were collected directly from the river bed.

Stream sediments were wet-sieved using a sieving machine. After drying, the 63-125 $\mu \mathrm{m}$ size fractions were treated with acetic acid to remove the carbonate component if present. The heavy mineral fractions were separated using sodium metatungstate with a density of $2.85 \mathrm{~g} / \mathrm{mL}$. The heavy mineral residues were mounted on microscope slides (Mange \& Maurer, 1992) using Meltmount ${ }^{\mathrm{TM}}$ with a refraction of 1.66 and identified under the polarising microscope, with the relative abundances determined by grain counting. For that, the microscope slide was moved along linear traverses and all grains between two parallel lines were counted (i.e., ribbon counting;
Mange \& Maurer, 1992). Two-hundred and fifty translucent minerals were point counted. Data of all heavy minerals including opaque minerals, micas and unknowns are given as supplementary data (see Supplementary Table S1) and in a second table only groups of transparent minerals are given (see Supplementary Table S2).

Garnet selection from the stream sediments was achieved by handpicking under a binocular microscope. We randomly selected garnet grains of all sizes and morphological types and set them in synthetic mounts. From the bedrock samples polished thinsections were prepared. Bedrock and stream samples were analysed with a JEOL JXA 8900 RL electron microprobe (EMP) equipped with five wavelength dispersive spectrometers at the University of Göttingen (Department of Geochemistry, Geoscience Center). Before analysis, all samples were coated with carbon to ensure conductivity. Conditions included an accelerating voltage of $15 \mathrm{kV}$ and a beam current of $20 \mathrm{nA}$. The counting times were 15 seconds for $\mathrm{Si}, \mathrm{Mg}, \mathrm{Ca}, \mathrm{Fe}$ and $\mathrm{Al}$, and 30 seconds for $\mathrm{Ti}, \mathrm{Cr}$ and $\mathrm{Mn}$. Matrix 
Table 2. Operating conditions of the electron microprobe for garnet analyses. Count time on the peak (in s), Bckg time counting time on background position (in s), DL detection limit (in ppm).

\begin{tabular}{|c|c|c|c|c|c|c|c|c|}
\hline Spectrometer & $1 T A P$ & $1 T A P$ & $2 T A P$ & 3 PETJ & 4 PETJ & 4 PETJ & $5 \mathrm{LIFH}$ & 5 LIFH \\
\hline Element (Line) & $\operatorname{Si}(K a)$ & $\mathrm{Al}(\mathrm{Ka})$ & $\mathrm{Mg}(\mathrm{K} \alpha)$ & $\mathrm{Ca}(\mathrm{Ka})$ & $\operatorname{Ti}(\mathrm{K} \alpha)$ & $\mathrm{Cr}(\mathrm{K} \alpha)$ & $\operatorname{Mn}(\mathrm{K} \alpha)$ & $\mathrm{Fe}(\mathrm{K} \alpha)$ \\
\hline Count time & 15 & 15 & 15 & 15 & 30 & 30 & 30 & 15 \\
\hline Bckg time & 5 & 5 & 5 & 5 & 15 & 15 & 15 & 5 \\
\hline Standard & $\begin{array}{l}\text { Garnet, } \\
\text { natural }\end{array}$ & $\begin{array}{l}\text { Garnet, } \\
\text { natural }\end{array}$ & $\begin{array}{c}\mathrm{MgO} \\
\text { synthetic }\end{array}$ & $\begin{array}{l}\mathrm{CaSiO}_{3} \\
\text { natural }\end{array}$ & $\begin{array}{c}\mathrm{TiO}_{2} \\
\text { synthetic }\end{array}$ & $\begin{array}{c}\mathrm{Cr}_{2} \mathrm{O}_{3} \\
\text { synthetic }\end{array}$ & $\begin{array}{c}\text { Rhodonite, } \\
\text { natural }\end{array}$ & $\begin{array}{c}\mathrm{Fe}_{2} \mathrm{O}_{3} \\
\text { synthetic }\end{array}$ \\
\hline DL & 160 & 138 & 104 & 138 & 113 & 135 & 117 & 216 \\
\hline
\end{tabular}

correction was performed using ZAF corrections. We preferentially analysed garnet rims and cores. Measurement conditions are also given in Table 2. The full database including lithology and metamorphic grade is presented in Supplementary Table S3.

\section{Results}

\section{Heavy mineral analysis}

Opaque minerals and micas are not considered in the diagram (Fig. 5) to illustrate the total concentration of transparent heavy minerals (HM).

Flatraket. The dominant heavy minerals are green calcic amphibole which represents $36 \%$ and epidote-group minerals (epidote, zoisite) which represent $39 \%$ of the heavy-mineral spectrum.
Here, zoisite is the most dominant mineral. Garnet, pyroxene, apatite and stable minerals (zircon, tourmaline and rutile) occur in minor percentages. Olivine, titanite and kyanite occur only in low percentages and are therefore grouped as 'others' (Fig. 5).

Ulvesund. The dominant heavy mineral is garnet, which represents $73 \%$ of the heavy-mineral spectrum. Green calcic amphibole, epidote-group minerals and apatite occur in relatively high percentages. Pyroxene and stable minerals (zircon, tourmaline and rutile) occur only in minor percentages. Kyanite occurs only in very low percentages and is therefore grouped as 'others' (Fig. 5).

Runde. The dominant heavy minerals are garnet, which represents $30 \%$, and green calcic amphibole, which represents $45 \%$ of the heavy-mineral spectrum. Epidote-group minerals, pyroxene, apatite and stable minerals (zircon, tourmaline and rutile) occur in minor percentages. Olivine, titanite and kyanite occur only in low percentages and are therefore grouped as 'others' (Fig. 5).

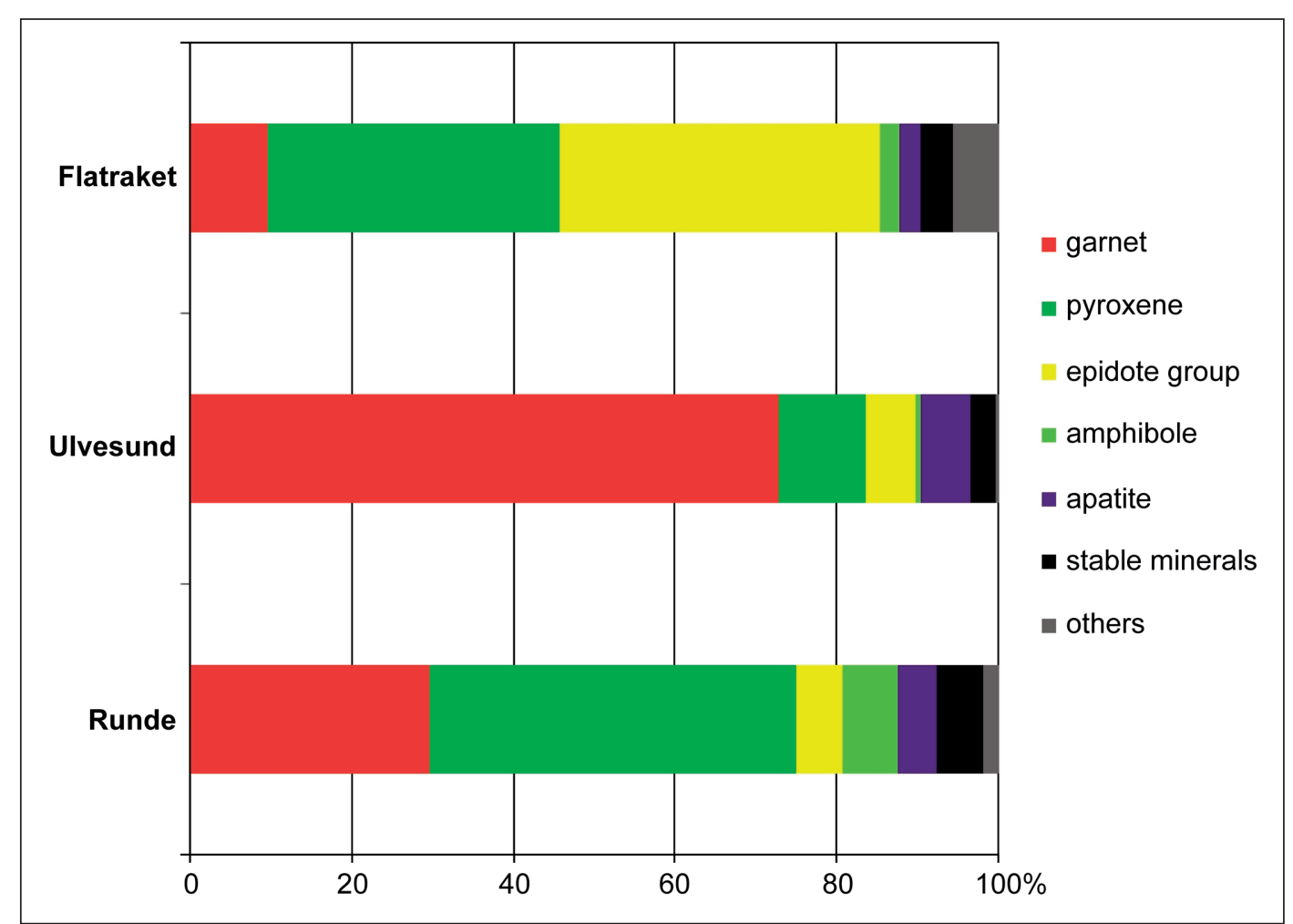

Figure 5. Figure showing the heavy-mineral assemblages of the samples from the three catchment areas. Epidote-group: epidote, zoisite; stable minerals: zircon, rutile, tourmaline; others: titanite, kyanite, olivine. 


\section{Garnet geochemistry}

The composition of garnets is illustrated in the ternary classification diagram of Mange \& Morton (2007) using almandine + spessartine, pyrope and grossular as poles, and the discrimination fields A, B, Bi, Ci, Cii and D (Fig. 6). This diagram has been applied widely in a number of garnet provenance studies (e.g., Morton et al., 2004, 2005, 2011; Whitham et al., 2004; Mange \& Morton, 2007; Meinhold et al., 2010).

Flatraket. Garnets of sample AK-N13-2a overlap three compositional fields ( $\mathrm{A}, \mathrm{Ci}$ and $\mathrm{Cii}$ ) but most of them are type $\mathrm{A}$ garnets (Fig. 6A). Most of the garnets from sample AK-N12 are type Cii garnets, some of them also plot in field Ci. Garnets of samples AK-N13-2b, AK-N13-2d and AK-N11 plot in field Ci. Garnets of sample AK-N16 plot in field $\mathrm{Ci}$ and field B. Garnets of sample AK-N13-2c are type B garnets. Most of the garnets from the stream sediment are type $\mathrm{Ci}$ garnets $(83 \%)$. Some of the garnets also plot in fields A (9\%), B (5\%), Bi (2\%) and Cii (1\%).

Ulvesund. Garnets of samples AK-N8-2 and AK-N9-1 are both type Ci garnets (Fig. 6B). Nearly all of the garnets from the stream sediment are type $\mathrm{Ci}$ garnets (95\%). A few garnets also plot in fields $\mathrm{A}(1 \%), \mathrm{Bi}(1 \%)$ and $\mathrm{Bi}(3 \%)$.
Runde. Garnets of sample AK-N39-1 plot in fields Bi and A (Fig. 6C). Garnets of sample AK-N38 plot in field Ci. Nearly all of the garnets from the stream sediment are type Ci garnets (85\%). A few garnets also plot in fields A (8\%) and B (7\%).

\section{Discussion}

Overall, the heavy-mineral association and garnet geochemical data reflect the geological setting of the study area, but some garnets measured in the basement rocks are lacking in the sediments. Detrital heavy minerals commonly reflect very well the situation in the source area. Geochemical data of heavy minerals often show a wider distribution in the sediments than the data of heavy minerals measured in the bedrock, because it was not always possible to sample all outcrop rocks due to difficult conditions in the source area. Our results reveal that this is not always the case.

The detrital garnets from all three study areas in western Norway reflect high-pressure conditions in the source area since almost all the garnets plot in field $\mathrm{Ci}$, the field for higher-grade metamorphic garnets. A few detrital garnets point to UHP conditions in the source area.

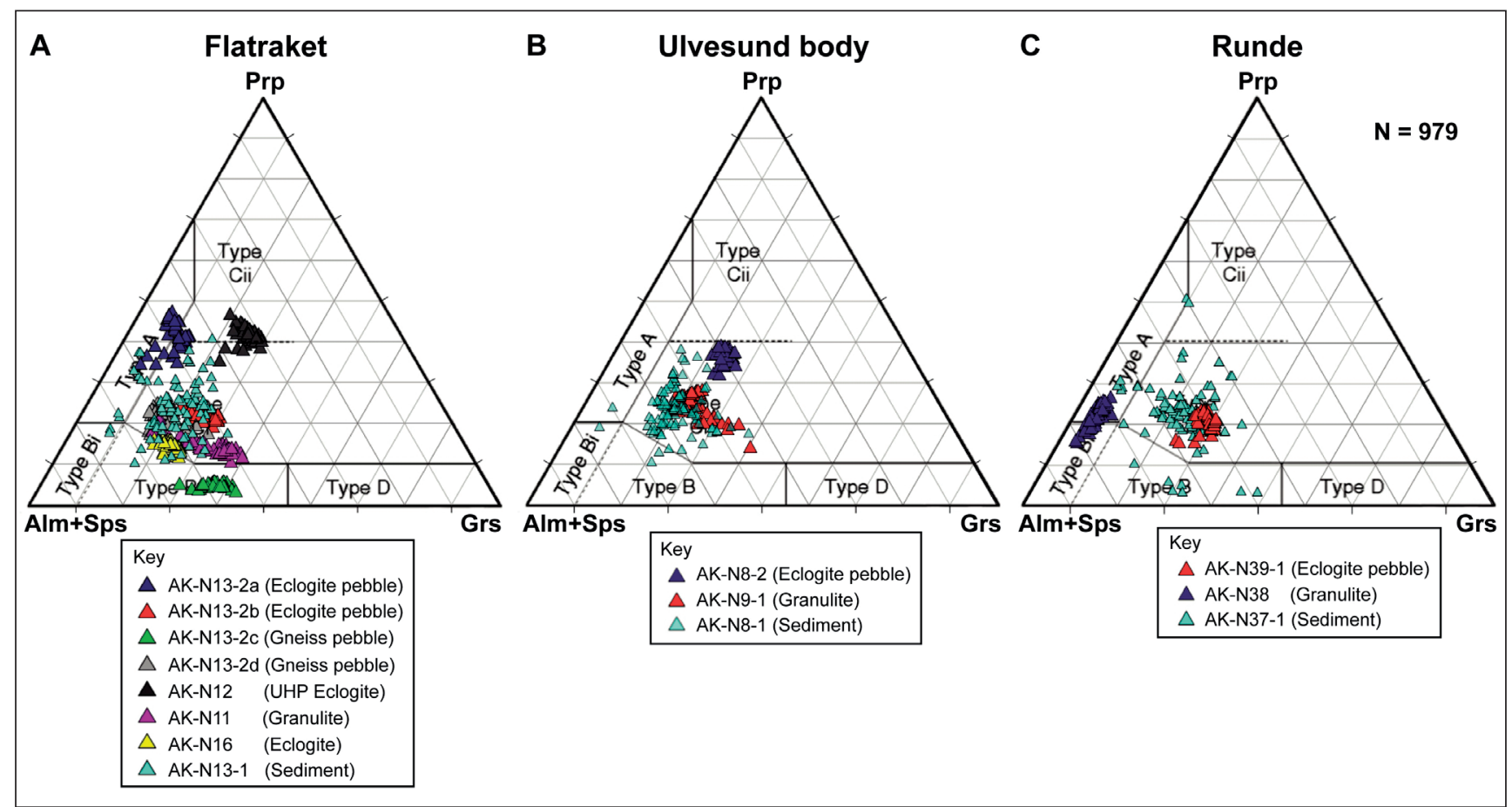

Figure 6. Figure showing the composition of garnets in the ternary classification diagram of Mange \& Morton (2007) with almandine + spessartine, grossular and pyrope as poles. (A) Composition of detrital garnets from the stream sediment and the basement rock samples from Flatraket. (B) Composition of detrital garnets from the stream sediment and bedrock samples from the Ulvesund body. (C) Composition of detrital garnets from the stream sediment and basement rock samples from the island of Runde. Type A - mainly from high-grade granulitefacies metasedimentary rocks or charnockites and intermediate felsic igneous rocks, Type B-amphibolite-facies metasedimentary rocks, Type $\mathrm{Bi}$ - intermediate to felsic igneous rocks, Type $\mathrm{Ci}$ - mainly from high-grade mafic rocks, Type Cii-ultramafic rocks with high $\mathrm{Mg}$ (pyroxenites and peridotites), Type D-metasomatic rocks, very low-grade metamafic rocks and ultrahigh-temperature, metamorphosed, calc-silicate granulites. Abbreviations: Alm - almandine, Sps - spessartine, Grs - grossular, Prp - pyrope, UHP - ultrahigh-pressure. 
The heavy-mineral assemblages from Flatraket, Ulvesund and Runde are comparable with garnet, green calcic amphibole and epidote-group minerals being the dominant heavy minerals, which reflect greenschist-facies and higher-grade metamorphism in the source area. The dominant heavy minerals in the stream sample from Flatraket are green calcic amphibole and epidotegroup minerals (almost $70 \%$ of the HM spectrum), which reflect the amphibolite-facies assemblages of the surrounding gneisses (Supplementary Table S4; Krabbendam et al., 2000). Garnet and pyroxene can be linked to the granulite- and eclogite-facies gneisses and mafic layers and pods (Supplementary Table S4), which occur widespread within the gneisses. The geochemical data show that the eclogites and granulites are the main sources of the detrital garnets. The garnets of the amphibolite-facies gneisses are not well represented in the stream sediment, probably because the gneisses only locally contain garnet grains. None of the garnets of the stream sediment sample from Flatraket overlap with the garnets from the gneiss pebble (sample AK-N13-2c). This possibly results from the coarser grain sizes of garnets in this sample. The garnet grains of sample AK-N13-2c are generally coarser than $500 \mu \mathrm{m}$ (Supplementary Table S5). Also, the gneiss contains very few garnet grains. Only a few detrital garnet grains show an overlap with garnets of the eclogite pebble (sample AK-N13-2a) and of the UHP eclogite (sample AK-N12). This is probably due to the original coarser size distribution in these source rocks.

The dominant heavy mineral of the sample from the Ulvesund body is garnet, which makes up more than $60 \%$ of the entire heavy-mineral spectra. Most of the Ulvesund body comprises medium- and fine-grained, garnetiferous felsic gneiss with dominantly amphibolite-facies assemblages, which represent remnants of granulite-facies assemblages. The geochemical data of the detrital garnets reflect higher-grade metamorphic conditions, because almost all of the detrital garnets plot in field Ci. In many samples a slight decrease of $\mathrm{MgO}$ from core to rim is visible, which shows that the garnets were affected by retrogression, but this is only marginally significant. Also, garnets measured in the bedrock show higher-grade metamorphic conditions. In summary, the heavymineral spectrum and the geochemical data from the stream sample of the Ulvesund body show a high overlap with garnets from the granulite (sample AK-N9-1), which is the main rock type exposed in the source area. Additionally, the granulite carries large amounts of garnets. Overall, the granulite is the main source of the detrital garnets.

The heavy-mineral spectrum of Runde is dominated by garnet and green calcic amphibole. The allochthonous cover units underwent high-pressure amphibolite-facies and a low-pressure granulitefacies overprint (Root et al., 2005). The geochemical data of the detrital garnets show that the garnets are derived mainly from high-grade metamorphic rocks, since they mostly overlap with garnets measured in the eclogite. Some of the detrital garnets are derived from lower-grade metamorphic rocks such as amphibolite-facies metasedimentary rocks and can probably be linked to the allochthonous cover units. There are also two type Cii garnets, which point to UHP conditions in the source area. This fits with the results of Root et al. (2004) who identified relict coesite (a UHP indicator mineral) in the cores of garnets from an eclogite collected from Runde. None of the garnets of the stream sediment sample from Runde overlap with the garnets of the garnet gneiss (sample AK-N39-1). This possibly results from the original coarser grain sizes of garnets in this sample (Supplementary Table S5).

The heavy-mineral assemblages are similar in Flatraket, Ulvesund and Runde, and vary only in proportions, probably depending on the distribution of their source rocks in the catchment area. The garnet compositions of all samples point to higher-grade metamorphic conditions since most of the garnets plot in field $\mathrm{Ci}$ with minor type Cii, type A, type B and type Bi garnets. UHP pressure conditions are only indicated in the stream sample of Flatraket and the beach sample of Runde. From both locations, eclogites containing relict coesite inclusions in garnets are known, which points to UHP conditions in each of these areas. UHP conditions are not evident in the garnets of rocks from the Ulvesund body. This is consistent with the lack of evidence for UHP eclogites in this area. Because the UHP eclogites of Flatraket and Runde are rather exceptional, garnets from these rocks, if any, occur only rarely in the sediment. Another possible factor is the original coarser grainsize distribution in some rocks. For example, most of the garnets of the UHP eclogite sampled in Flatraket (AK-N12) are coarser than $500 \mu \mathrm{m}$. Nonetheless, very few detrital garnets point to a derivation from these UHP rocks.

The Trollebøelva stream drains the granulite of the Ulvesund body (Fig. 3), which explains the high input of garnet grains, which in turn reflects the high-pressure conditions in this area. Type B garnets are most evident in the sample from Runde. This is not surprising because garnet is common in the metasedimentary units of the allochthonous cover units in contrast to the amphibolite-facies gneisses of the basement. Therefore, the content of lower-grade metamorphic garnet is higher on the island of Runde in contrast to the other two study areas. In the samples of Flatraket and Ulvesund, the input of lower-grade metamorphic garnet may be diluted by the high input of higher-grade metamorphic garnet, because the content of garnet is higher in the rocks with granulite- and eclogite-facies assemblages. Also possible is the grain-size inheritance from source to sediment, as some samples of the amphibolite-facies gneisses have large garnet grains $(>125 \mu \mathrm{m}$ in size) and are therefore not evident in the analysed grain-size fraction from 63 to $125 \mu \mathrm{m}$ (Supplementary Table S5).

The three catchment areas form part of the N4 area in Morton et al. (2004), who studied garnet from river sediments from different parts of western Norway. In the study of Morton et al. (2004), 54\% of the garnets plot in field C. Our data yield far more type C garnets (c. $80-95 \%$ of the data plot in field C). This suggests that our samples are completely influenced by the input from the crystalline basement. Samples of the N4 area of Morton et al. (2004) also contain some type B garnets, which are almost lacking in our samples. This is probably due to the fact that some of the sample localities of Morton et al. (2004) are within areas with Caledonian cover units, which are more heterogeneous than the crystalline basement. 


\section{Conclusions}

The heavy-mineral and garnet geochemical data very well reflect the geological situation in all three study areas. The dominant rock type in the areas is a layered micaceous quartzo-feldspathic gneiss. The gneisses show amphibolite-facies assemblages of green calcic amphibole \pm epidote-group and \pm garnet (Krabbendam et al., 2000), which is evident in the heavy-mineral spectra. In the three study areas, most of the garnets are derived from higher-grade metamorphic rocks such as eclogites and granulites, because these rocks have a high content of garnet in contrast to the amphibolite-facies gneisses which mainly contain green calcic amphibole, epidote-group minerals and only locally garnets. This is most clearly seen in the sample from the Ulvesund body where the stream drains the granulite, which carries huge amounts of garnet grains. However, some detrital garnets cannot be linked to the garnets analysed in the bedrock, especially garnets derived from amphibolite-facies gneisses. On the one hand, this may be due to dilution by a strong influx of garnets from higher-grade metamorphic rocks, but, on the other hand this may result from the original coarser grain size of garnets in the host rocks. Even though UHP eclogites are only very rarely exposed in the study area, they are obvious in the detrital garnets of Flatraket and Runde. Thus, with only little effort (one sample per stream) it is possible to obtain a relatively clear picture about the study area. However, to maximise the amount of provenance information, a larger number of samples from a variety of locations should be used, as well as a wider grain-size range (see Krippner et al., 2015). Nevertheless, our results underline the applicability of heavy minerals and the power of garnet geochemistry in sedimentary provenance analysis.

Acknowledgements. The Ph.D. scholarship of AK is financed by CASP. Fieldwork and analytical work was financed by the German Research Foundation (DFG grant EY 23/20-1). We thank Andreas Kronz for his help with electron microprobe analyses, and Anders Mattias Lundmark and an anonymous reviewer for their constructive and helpful comments.

\section{Reference list}

Andersen, T.B., Jamtveit, B., Dewey, J.F. \& Swensson, E. 1991: Subduction and education of continental crust: major mechanism during continent-continent collision and orogenic collapse, a model based on the south Norwegian Caledonides. Terra Nova 3, 303-310.

Andò, S. 2007: Heavy minerals: provenance, hydraulic sorting, weathering. PhD Thesis, University of Milano-Bicocca, 210 pp.

Andò, S., Morton, A.C. \& Garzanti, E. 2014: Metamorphic grade of source rocks revealed by chemical fingerprints of detrital amphibole and garnet. In Scott, R.A., Smyth, H.R., Morton, A.C. \& Richardson, N. (eds.): Sediment Provenance Studies in Hydrocarbon Exploration and Production, Geological Society of London, Special Publications 386, pp. 351-371.

Beyer, E.E., Brueckner, H.K., Griffin, W.L. \& O’Reilly, S.Y. 2012: Laurentian Provenance of Archean Mantle Fragments in the Proterozoic Baltic Crust of the Norwegian Caledonides. Journal of
Petrology 53, 1357-1383.

Brueckner, H.K. 1998: Sinking intrusion model for the emplacement of garnet-bearing peridotites into continent collision orogens. Geology 26, 631-634.

Brueckner, H.K. \& van Roermund, H.L.M. 2004: Dunk tectonics: a multiple subduction/eduction model for the evolution of the Scandinavian Caledonides. Tectonics 23, TC2004. doi:10.1029/2003TC001502.

Bryhni, I. \& Andréasson, P.G. 1985: Metamorphism in the Scandinavian Caledonides. In Gee, D.G. \& Sturt, B.A. (eds.): The Caledonide orogen - Scandinavia and related areas, John Wiley \& Sons, Chichester, pp. 763-781.

Carswell, D.A. \& Cuthbert, S.J. 2003: Review of the mineralogical and microstructural evolution of ultra-high pressure eclogites in the Western Gneiss Region of Norway. In Carswell, D.A., Cuthbert, S.J., Krabbendam, M., Medaris, L.G. \& Brueckner, H.K. (eds.): Guidebook to the field exkursions in the Nordfjord - Stadtlandet Almklovdalen area, Norges geologiske undersøkelse Report 2003.056, pp. 3-47.

Carswell, D.A., Brueckner, H.K., Cuthbert, S.J., Mehta, K. \& O’Brien, P.J. 2003: The timing of stabilisation and the exhumation rate for ultra-high pressure rocks in the Western Gneiss Region of Norway. Journal of Metamorphic Geology 21, 601-612.

Deer, W.A., Howie, R.A. \& Zussman, J. 1992: An introduction to rockforming minerals. Longman Group Ltd., Harlow, UK, 712 pp.

Garzanti, E., Andò, S. \& Vezzoli, G. 2008: Settling-equivalence of detrital minerals and grain-size dependence of sediment composition. Earth and Planetary Science Letters 273, 138-151.

Garzanti, E., Andò, S. \& Vezzoli, G. 2009: Grain-size dependence of sediment composition and environmental bias in provenance studies. Earth and Planetary Science Letters 277, 422-432.

Garzanti, E., Resentini, A. \& Vezzoli, G. 2010: Detrital fingerprints of fossil continental-subduction zones (Axial Belt Provenance, European Alps). Journal of Geology 118, 341-362.

Gebauer, D., Lappin, M.A., Grunenfelder, M. \& Wyttenbach, A. 1985: The age and origin of some Norwegian eclogites: a U-Pb zircon and REE study. Chemical Geology 52, 22-47.

Griffin, W.L. \& Brueckner, H.K. 1980: Caledonian Sm-Nd ages and a crustal origin of Norwegian eclogites. Nature 285, 319-321.

Griffin, W.L. \& Brueckner, H.K., 1985: REE, Rb-Sr and Sm-Nd studies of Norwegian eclogites. Chemical Geology 52, 249-271.

Griffin, W.L., Austrheim, H., Brastad, K., Bryhni, I., Krill, A.G., Krogh, E.J., Mørk, M.B.E., Qvale, H. \& Torudbakken, B. 1985: Highpressure metamorphism in the Scandinavien Caledonides. In Gee, D.G. \& Sturt, B.A. (eds.): The Caledonide orogen - Scandinavia and related areas, John Wiley \& Sons, Chichester, pp. 783-801.

Hacker, B.R., Andersen, T.B., Johnston, S., Kylander-Clark, A.R.C., Peterman, E.M., Walsh, E.O. \& Young, D. 2010: High-temperature deformation during continental-margin subduction \& exhumation: The ultrahigh-pressure Western Gneiss Region of Norway. Tectonophysics 480, 149-171.

Krabbendam, M. \& Wain, A. 1997: Late-Caledonian structures, differential regression and structural position of (ultra)highpressure rocks in the Nordfjord-Stradlandet area, Western Gneiss Region. Norges Geologiske Undersøkelse 432, 127-139.

Krabbendam, M., Wain, A. \& Andersen, T.B. 2000: Pre-Caledonian granulite and gabbro enclaves in the Western Gneiss Region, Norway: indications of incomplete transition at high pressure. Geological Magazine 137, 235-255.

Krippner, A., Meinhold, G., Morton, A.C. \& von Eynatten, H. 2014: Evaluation of garnet discrimination diagrams using geochemical data derived from various host rocks. Sedimentary Geology 306, 36-52.

Krippner, A., Meinhold, G., Morton, A.C., Russell, E. \& von Eynatten, H. 2015: Grain-size dependence of garnet composition revealed by provenance signatures of modern stream sediments from the western Hohe Tauern (Austria). Sedimentary Geology 321, 25-38.

Kylander-Clark, A.R.C., Hacker, B.R. \& Mattinson, J.M. 2008: Slow 
exhumation of UHP terranes: Titanite and rutile ages of the Western Gneiss Region, Norway. Earth and Planetary Science Letters 272, 531-540.

Mange, M.A. \& Maurer, H.F.W. 1992: Heavy minerals in color. Chapman and Hall, London, $147 \mathrm{pp}$.

Mange, M.A. \& Morton, A.C. 2007: Geochemistry of heavy minerals. In Mange, M.A. \& Wright, D.T. (eds.): Heavy minerals in use, Developments in Sedimentology 58, Elsevier, Amsterdam, pp. 345391.

Meinhold, G., Reischmann, T., Kostopoulos, D., Frei, D. \& Larionov, A.N. 2010: Mineral chemical and geochronological constraints on the age and provenance of the eastern Circum-Rhodope Belt lowgrade metasedimentary rocks, NE Greece. Sedimentary Geology 229, 207-223.

Miyashiro, A. 1953: Ca-poor garnet in relation to metamorphism. Geochimica et Cosmochimica Acta 4, 179-208.

Morton, A.C. \& Hallsworth, C.R. 1999: Processes controlling the composition of heavy mineral assemblages in sandstones. Sedimentary Geology 124, 3-29.

Morton, A., Hallsworth, C. \& Chalton, B. 2004: Garnet compositions in Scottish and Norwegian basement terrains: a framework for interpretation of North Sea sandstone provenance. Marine and Petroleum Geology 21, 393-410.

Morton, A.C., Whitham, A.G. \& Fanning, C.M. 2005: Provenance of Late Cretaceous to Paleocene submarine fan sandstones in the Norwegian Sea: integration of heavy mineral, mineral chemical and zircon age data. Sedimentary Geology 182, 3-28.

Morton, A.C., Meinhold, G., Howard, J.P., Phillips, R.J., Strogen, D., Abutarruma, Y., Elgadry, M., Thusu, B. \& Whitham, A.G. 2011: A heavy mineral study of sandstones from the eastern margin of the Murzuq Basin, Libya: constraints on provenance and stratigraphic correlation. Journal of African Earth Sciences 61,308-330.

Mørk, M.B.E. \& Mearns, E.W. 1986: Sm-Nd isotopic systematics of a gabbro-eclogite transition. Lithos 19, 255-267.

Nandi, K. 1967: Garnets as indices of progressive regional metamorphism. Mineralogical Magazine 36, 89-93.

Roberts, D.C. \& Gee, D.G. 1985: An introduction to the structure of the Scandinavian Caledonides. In Gee, D.G. \& Sturt, B.A. (eds.): The Caledonide orogen - Scandinavia and related areas, John Wiley \& Sons, Chichester, pp. 55-68.

Root, D.B., Hacker, B.R., Mattinson, J.M. \& Wooden, J.L. 2004: Zircon geochronology and ca. $400 \mathrm{Ma}$ exhumation of Norwegian ultrahigh-pressure rocks: an ion microprobe and chemical abrasion study. Earth and Planetary Science Letters 228, 325-341.

Root, D.B., Hacker, B.R., Gans, P.B., Duccea, M.N., Eide, E.A. \& Mosenfelder, L. 2005: Discrete ultrahigh-pressure domains in the Western Gneiss Region, Norway: Implications for formation and exhumation. Journal of Metamorphic Geology 23, 45-61.

Schuiling, R.D., de Meijer, R.J., Riezebos, H.J. \& Scholten, M.J. 1985: Grain-size distribution of different minerals in a sediment as a function of their specific density. Geologie en Mijnbouw 64, 199-203.

Spencer, K.J., Hacker, B.R., Kylander-Clark, A.R.C., Andersen, T.B., Cottle, J.M. \& Stearns, M.A. 2013: Campaign-style titanite U-Pb dating by laser-ablation ICP: Implications for crustal flow, phase transformations and titanite closure. Chemical Geology 341, 84-101.

Spengler, D., Brueckner, H.K., van Roermund, H.L.M., Drury, M.R. \& Mason, P.R.D. 2009: Long-lived, cold burial of Baltica towards 200 $\mathrm{km}$ depth. Earth and Planetary Science Letters 281, 27-35.

Terry, M.P. \& Robinson, P. 2004: Geometry of eclogite-facies structural features: Implications for production and exhumation of ultrahighpressure and high-pressure rocks, Western Gneiss Region, Norway. Tectonics 23, 1-23.

Thoresen, M.K. 1990: Kvartærgeologisk kart over Norge, scale 1:1.000,000. Tema: Jordarter. Norges geologiske undersøkelse, 64 pp.

Tiberg, E. 1998 (ed.): Nordic Reference Soils. 1. Characterisation and classification of 13 typical Nordic soils. 2. Sorption on 2,4 D, Atrazine and Glyphosphate. Tema Nord 537, Nordic Council of Ministers, Copenhagen, Denmark, 106 pp.
Tucker, R.D., Krogh, T.E. \& Råheim, A. 1990: Proterozoic evolution and age-province boundaries in the central part of the Western Gneiss Region, Norway; results of $\mathrm{U}-\mathrm{Pb}$ dating of accessory minerals from Trondheimsfjord to Geieranger. In Gower, C.F., Rivers, T. \& Ryan, B. (eds.): Mid-Proterozoic Laurentia-Baltica, Geological Association of Canada, Special Paper 38, pp. 149-73.

von Eynatten, H., Tolosana-Delgado, R. \& Karius, V. 2012: Sediment generation in modern glacial settings: Grain-size and source-rock control on sediment composition. Sedimentary Geology 208, 80-92.

Wain, A. 1997: New evidence for coesite in eclogite and gneisses: defining an ultrahigh-pressure province in the Western Gneiss region of Norway. Geology 25, 927-930.

Wain, A.L., Waters, D.J. \& Austrheim, H. 2001: Metastability of granulites and processes of eclogitisation in the UHP region of western Norway. Journal of Metamorphic Geology 19, 607-623.

Wang, Q., Xia, Q.-K., O’Reilly, Y., Griffin, W.L., Beyer, E.E. \& Brueckner, H.K. 2013: Pressure- and stress-induced fabric transition in olivine from peridotites in the Western Gneiss Region (Norway): implications for mantle seismic anisotropy. Journal of Metamorphic Geology 31, 93-111.

Whitham, A.G., Morton, A.C. \& Fanning, C.M. 2004: Insights into Cretaceous-Palaeogene sediment transport paths and basin evolution in the North Atlantic from a heavy mineral study of sandstones from southern East Greenland. Petroleum Geoscience 10, 61-72. 
